\title{
LEGAL ARRANGEMENTS OF INDONESIAN MIGRANT WORKERS
}

\author{
Abdul Maasba Magassing*, S.M. Noor ${ }^{*}$, Iin Karita Sakharina, ${ }^{* *}$ Kadarudin $^{* * *}$ \\ *Professor, Faculty of Law, Hasanuddin University, Indonesia \\ ${ }^{* *}$ Assoc. Professor, Faculty of Law, Hasanuddin University, Indonesia \\ ${ }^{* * *}$ Lecturer, Faculty of Law, Hasanuddin University, Indonesia
}

\begin{abstract}
The activity of placing Indonesian migrant workers abroad has problems that are detrimental to migrant workers and the state, limitations and deviations in implementation can be found in planning, implementation and weak supervision. In terms of planning and operations there are weaknesses in managing information on job vacancies abroad and how prospective TKIs are prepared. The utilization of foreign employment opportunities is still in the informal sector (use of services not incorporated). Even if the placement in the formal sector continues to increase, but in terms of the quality of TKI, it is limited to filling in positions that only require basic skills such as those placed in Malaysia. The Malaysian immigration office recorded foreign workers from 22 countries totaling 1,914,053, more than three-fifths (61.46\%) coming from Indonesia. Those who worked as household managers in the middle of 2007 numbered approximately 320,000 people, the largest part of this type of work (PLRT / PRT) reached a total of 300,000 female workers from Indonesia.
\end{abstract}

Keywords: arrangements, Indonesia, migrant workers.

DOI: $10.7176 / \mathrm{IAGS} / 74-08$

Publication date:July $31^{\text {st }} 2019$

\section{Introduction}

Labor migration "is a term used to describe movement/migration carried out by people from one place to another, with the aim of working or finding work". When migrating, they are classified as "migrant workers". Labor migration covers various types of migrant workers, ranging from less skilled to semi-skilled and highly skilled contract workers. In the context of labor migration, the countries in which migrants originate are referred to as "sending countries" and the destination countries are referred to as "destination countries" or "host countries". 1

International labor migration is the process of moving people from one country to another based on various reasons, one of which is to get a job. According to the International Labor Organization ${ }^{2}$ it is estimated that more than 231 million people carry out international migration. Besides that, the Indonesian Ministry of Foreign Affairs noted that there were 2.7 million Indonesian citizens abroad, where more than $90 \%$ worked to get a decent livelihood. Migration has a positive impact on the perpetrators of migration itself and for the country of origin, starting from the fulfillment of employment opportunities for workers to remittances that can drive the economy in the country of origin. Nevertheless, the magnitude of the international migration flow of the workforce also has logical consequences for the emergence of various challenges that must be faced. ${ }^{3}$ Indonesian migrant workers, known as Indonesian Migrant Workers (TKI), mostly work in the informal sector and have a low level of education, so they are in a vulnerable or unprofitable position, with such conditions often being victims of exploitation. ${ }^{4}$

Over the years there have been many reports that Indonesian migrant workers have suffered cruel conditions abroad and have raised concerns. In 2018, Tuti Tursilawati was executed in Saudi Arabia after killing her employer who allegedly harassed her. In February, Adelina Lisao died after Malaysian authorities found her in critical condition at her employer's house. He suffered from malnutrition, and was found with evidence of torture on his body. As of September 2018, BNP2TKI received 18 complaints of physical or sexual violence

\footnotetext{
${ }^{1}$ ILO, Perlindungan \& Pencegahan Untuk Pekerja Migran Indonesia, Jakarta, without year, p. 3-4

${ }^{2}$ ILO World of Work Report 2014

${ }^{3}$ Policy Assessment and Development Agency of the Ministry of Foreign Affairs Policy, 2016, Basic Position of Indonesian Foreign Policy, Indonesian Ministry of Foreign Affairs, p. 431

${ }^{4}$ Abdul Maasba Magassing, et.al., Use of the Memorandum of Understanding Model on Legal Protection of Indonesia Migrant Workers, Journal of Law, Policy and Globalization, Vol. 67, 2017, p. 218
} 
committed by employers, and in 2017 there were 55 complaints. ${ }^{1}$ The Indonesian government has an obligation to provide protection for Indonesian workers. This is in accordance with the 1945 Constitution of the Republic of Indonesia which guarantees that every citizen of Indonesia has equal rights and opportunities without discrimination, to obtain employment and decent livelihoods. The protection of Indonesian workers abroad is an effort to realize equal rights and opportunities for Indonesian workers to obtain decent jobs and income in accordance with their skills, talents, interests and abilities, whose implementation is carried out while paying attention to dignity, human rights human and legal protection, as well as equal employment opportunities and the supply of labor in accordance with national needs.

Until now, they still have not found the right, effective and efficient solution format so that they can really overcome the problems that are often experienced by them. ${ }^{2}$ One of the government's efforts to realize a decent life is pursued through a policy that we know as a program to reduce employment opportunities and the utilization of labor with an inter-work mechanism. Through a mechanism between local work and regional work, the issue of employment utilization has not been resolved, because of limited domestic sectoral absorption, a workforce placement program has been developed through a mechanism for inter-state employment by placing Indonesian workers abroad. ${ }^{3}$

Placement of migrant workers outside is done through a process that begins with preparation, placement and repatriation to the area of origin. In the Law Number 18 Year 2017 concerning the Protection of Indonesian Migrant Workers has been stated "that the State must guarantee and protect the human rights of its citizens who work both inside and abroad based on the principle of equality, democracy, social justice, gender equality and justice, non-discrimination, non-people smuggling ${ }^{4}$ and non-trafficking in persons". and "In the context of the service of placement of Indonesian migrant workers abroad, it is necessary to do it in an integrated manner between the central and regional Government agencies and the participation of the community in a legal system to protect Indonesian workers who are placed abroad".

To ensure the protection of migrant workers who work abroad, the Indonesian government continues to make various efforts so that migrant workers can work comfortably and obtain maximum protection. One of the efforts made is to make a bilatelar agreement with the destination country for sending migrant workers. In addition, the commitment of the Indonesian government is shown by active participation in the discussion of various international legal instruments related to the rights of migrant workers. ${ }^{5}$

The protection of migrant workers or migrant workers is often considered the domain of the labor law of the recipient country of migrant workers; therefore, the protection of their rights is highly dependent on the goodwill of the recipient country and the goodwill of the employers. The government cannot implement the placement and protection of workers from the eyes of national law alone. The protection of migrant workers has an international dimension which includes bilateral cooperation relations with the recipient country and the subject of state law. ${ }^{6}$

Today, in regional forums, the Indonesian government actively participates in "ASEAN Instruments on Protection and Promotion of the Rights of Migrant Workers" or also known as the ASEAN Declaration on Migrant Workers, in 2007. This instrument is intended to be a legal protection umbrella for migrant workers in the ASEAN region. While at the multilateral level, Indonesia has ratified the "International Convention on the Protection of the Rights of All Migrant Workers and Members of Their Families" with Republic of Indonesia

\footnotetext{
${ }^{1}$ VOA Indonesia: Aktivis: Pekerja Migran Indonesia Masih Rentan Terhadap Berbagai Perlakuan Kejam, November 12, 2018 edition, see https://www.voaindonesia.com/a/aktivis-pekerja-migran-indonesia-masih-rentan-terhadap-berbagai-perlakuankejam/4654625.html

${ }^{2}$ Nurdin Widodo, Permasalahan Tenaga kerja Indonesia di daerah Asal: Studi Kasus Kabupaten Tulungagung Jawa Timur. Jurnal penelitian dan Pengembangan Kesejahteraan Sosial, Vol. 14, No. 1, 2009, p. 33-46

${ }^{3}$ Fadjri, et.al., 2010, Pelayanan, Penempatan, dan Perlindungan Tenaga Kerja Indonesia, Kasus Pendataan Selapajang, Leuser Cita Pustaka, Jakarta, p.1-2

${ }^{4}$ People smuggling and illegal immigrants are interrelated criminal acts. Such activities can occur if one of them can be realized, in the sense that illegal immigrants will succeed with the conspiracy of smuggling agents, and people smugglers resulting in an increasing number of illegal immigrants, see Kadarudin, People Smugling Dalam Perspektif Hukum Internasional dan Penegakan Hukumnya di Indonesia, Jurnal Perpustakaan, Informasi dan Komputer "Jupiter" Vol. XII No. 2, 2013, UPT. Perpustakaan Universitas Hasanuddin. p. 69-70

${ }^{5}$ Policy Assessment and Development Agency of the Ministry of Foreign Affairs Policy, 2016, Basic Position of Indonesian Foreign Policy, Indonesian Ministry of Foreign Affairs, p. 436

${ }^{6}$ Koesrianti, 2010, Kewajiban Negara Pengirim dan Negara Penerima Atas Perlindungan Pekerja Migran, Jurnal Diplomasi, Vol. 2. No. 1
} 
Law Number 6 Year 2012. This is to show a high commitment from the Government of Indonesia to protect migrant workers / migrant workers abroad by referring to the standards at the convention.

From the description, it can be stated that the attitude of the state both as a sending country of migrant workers and as recipients of migrant workers still has different attitudes and views even though their country has become a party to both regional instruments and multilateral conventions on the protection of migrant workers. Therefore, in this study further research will be carried out on the following matters:

- Whereas there is a need to develop programs that support the development of the expertise of migrant workers;

- Consequences if the recipient country does not ratify the convention then the convention becomes ineffective. Therefore, the need for strengthening bilateral agreements, including in the form of a MoU whose content is parallel to the convention.

- Prevention and eradication of human trafficking (human trafficking);

- Harmonization of national labor law with international labor standards.

\section{Research Method}

The type of research used is a type of normative legal research, using a statute and conceptual approach. ${ }^{1}$ Data collection techniques carried out through library research by studying and reviewing a number of national legal regulations and international agreements, textbooks, research reports, legal journals, legal dictionaries, and then analyzed descriptively.

\section{Results and Discussion}

The Constitution of the Republic of Indonesia 1945 guarantees that every Indonesian citizen has the same rights and opportunities without discrimination to get a job and decent livelihood. Working is a human right that must be upheld, respected, and guaranteed by enforcement. Indonesian Migrant Workers must be protected from human trafficking, including slavery and forced labor, victims of violence, abuse, crime over dignity and human dignity, as well as other treatments that violate human rights human. The protection of Indonesian Migrant Workers needs to be carried out in an integrated system involving the central government, regional government, and the community. The Protection of Indonesian Migrant Workers includes institutional protection that regulates the duties and authorities of ministries as regulators/policy makers with the Agency as operator/implementer of the policy. This gives firmness to both the duties and authorities of ministries and agencies, given the problems that have existed so far are due to the dualism of authority between the two parties. The Action on the Protection of Indonesian Migrant Workers is carried out by a body established by the president. Furthermore, the role of the Regional Government in providing protection to Indonesian Migrant Workers is carried out starting from the village, district / city, and province, from before work until after work. Regional Governments have a role starting from providing information on requests (job orders) originating from Representatives of the Republic of Indonesia, Employers, and Business Partners abroad. ${ }^{2}$

The issue of Indonesian migrant workers abroad seems never to be completed, even when it concerns trafficking. ${ }^{3}$ The activities of migrant workers have been going on for a long time. The European Agency for Safety and Health at work says, in the 1950s and 1960s was the period of mass migration. The culprit is men who are looking for unskilled jobs in several countries such as Sweden, Britain, the Netherlands and Germany. In this period, it is also marked by the diversity of the countries of origin of the migrants. For example, Britain received migrants from its former colonial, while Sweden without significant colonial relations, received migrants from countries on the edge of rural Europe. Migration of mass workers ended in the early 1970s when an oil crisis broke out in 1973. Then bloom again along with globalization and other causes that can not be separated from economic factors. Lately, the phenomenon of migrant workers that is classified as striking is to the Middle East. The UN labor organization noted in its release on May 21, 2004, nearly half of all migrants in the world ( 86 million) were workers. Between 10 and $15 \%$ are illegal workers. This is not limited to developed countries. "This indicates that the demand for legal migrant workers is not balanced with supply". Migrant workers in each country turned out to have different country preferences. Migrant workers from Maghreb

\footnotetext{
${ }^{1}$ Peter Mahmud Marzuki, Penelitian Hukum, Jakarta: Kencana, 2011, p. 35

${ }^{2}$ General Explanation of the Law Number 18 Year 2017 concerning the Protection of Indonesian Migrant Workers

${ }^{3}$ R.A.W. Ajeng, Kerjasama BNP2TKI Dengan IOM dalam Menangani Human Trafficking Tenaga Kerja Indonesia Di Malaysia Periode 2011-2015, Journal of International Relations, Vol. 2, No. 1, 2016, p. 189-190
} 
countries, for example, are very fond of working in Western European countries, such as France, Germany, England.

America is a magnet for migrant workers. The Labor Statistics Agency noted that in 2012 there were 25 million migrant workers, or $16.1 \%$ of the total employed. The largest portion (38\%) of migrant workers are from Mexico and Central America, 28\% are from Asia (including the Middle East). While migrant workers from Europe, the Caribbean are $10 \%$ each. Along with the times, migrant workers are not only dominated by adam, but also from among women. They generally work in private homes as housemaids, caregivers and elderly people. There are also those who work in factories and shops. They have given great benefits to the economic strength of their families (although there are also many studies that show that there are opportunity costs to be borne, such as infidelity, increased divorce rates, and decreased household stability). ${ }^{1}$

Benefits also obtained by the country of origin of migrant workers. They contribute to remittance to their country. The World Bank estimates that in 2012 developing countries will receive remittance shipments of around USD 406 billion from citizens who work abroad. This number increased $6.5 \%$ compared to last year. Projected, the numbers continue to rise, namely $7.9 \%$ in $2013,10.1 \%$ in 2014 , and $10.7 \%$ in 2015 or reach USD 534 billion (Behind the benefits provided by these international migrant workers for their respective countries. The ILO is concerned about the existence of several countries of origin these migrant workers who seem to have developed an "emigration culture"). The movement of international migrant workers in various countries creates a new phenomenon, namely the formation of migrant trade unions. They actively initiate various movements against oppression and human rights violations that are often experienced by others. They also agreed on March 1 as the day of the movement of international migrant workers. This momentum coincides with the initiation that took place in America on March 1, 2006 which has sparked a sense of solidarity among migrant workers in other countries to take the same action. In Austria the strike of the first migrant worker (Transnationaler Migrant innenstreik) took place in March 2011.

Indonesian labor migration has also been going on for a long time. That is since the days of colonialism until now. Even then the migration experiences variations in aspects of the background and ways. Early records of migrating Indonesian workers abroad, from Java to Suriname can be found in Hassankhan and Hira (2000). They were employed at the Marienur Plantation by the Nederlandse Handelsmaatschappij owned by the Dutch Colonial government in 1890. ${ }^{2}$ From 1890-1939 the total number of workers migrated reached 32965 people. After Indonesia's independence, the Constitution of the Republic of Indonesia in particular Article 27 paragraph (2) mandates "every citizen has the right to obtain decent work and livelihood for humanity". This means that the State guarantees that every citizen gets a decent job and income.

In fact, it's difficult. Many Indonesians depart in various ways abroad, especially countries bordering land and sea, such as Malaysia. Some of them even become Malaysians. In its development, the trend of overseas migration is increasing. This fact is used by some people to be used as business land. They take care of the departure of people from various regions to work abroad, in a way and their shrewdness is barely managed by the state. The practice lasts a dozen years. Only, in 1969 the Indonesian Ministry of Labor regulated and supervised the placement of Indonesians working abroad, which became popular as the name of Indonesian migrant workers. The rules contained in Government Regulation No. 4 Year 1970 concerning Inter-Work, the Inter-State Inter-Work Program (Antar Kerja Antar Negara/AKAN) is permitted. The placement of migrant workers involves the private sector.

Various cases of abuse, rape by employers is still often found in Indonesian migrant workers. ${ }^{3}$ The effectiveness of the placement of TKIs was formed by the Indonesian Migrant Worker Placement Service Center (BP2TKI) in the regional provinces from TKI. BP2TKI serves as a one-stop service, to simplify, cheapen, speed up, and secure the process of placing Indonesian migrant workers. The TKI Placement Coordination Agency (BKPTKI) was also formed on April 16, 1999 through Presidential Decision No. 29 Year 1999. Membership of BKPTKI consisted of nine relevant cross-sectoral agencies to improve the PTKLN program in accordance with

\footnotetext{
${ }^{1}$ One interesting analysis of female migrant workers can be seen in a study conducted by Brenda Yeoh, et.al., 2000, Global Cities, Transnational Flows and Gender Dimensions: The View from Singapore. Departement of Geography, Univ.of Singapore, Royal Dutch Geographical Society KNAG in Muhaimin Iskandar, Pisau Bermata Dua: Menuju Cita TKI yang Bermartabat dan Bermanfaat, Jakarta: Kementerian Tenaga Kerja dan Transmigrasi, 2014, p. 8

${ }^{2}$ In Muhaimin Iskandar, 2014, Ibid., p. 8

${ }^{3}$ S. Djuni Prihatin, Potret Buram Perlindungan Tenaga Kerja Indonesia, Jurnal Ilmu Sosial dan Ilmu Politik Vol. 10, No. 3, 2007, p. 325- 342
} 
their respective scope of duties. In 2003, Indonesia had a new law on employment, namely Law No.13 Year 2003 concerning Manpower. Regarding the placement and protection of migrant workers, this Law mandates the need for special laws governing this. A year later, Law Number 18 Year 2017 was issued concerning the Protection of Indonesian Migrant Workers.

At the national level of Indonesia. The 1945 Constitution Article 27 (2) states that every state institution has the right to decent work for life. That is, the obligation for the Indonesian government to guarantee that a decent life is obtained for every citizen. Government services in the context of the realization of life that is worth pursuing through policies to expand employment opportunities and the utilization of labor, one of which uses inter-work mechanisms. domestic, the employment placement program is developed through a mechanism of inter-country work by placing Indonesian workers abroad. The placement of Indonesian labor migrants abroad is carried out through a process that begins with preparing, placing and returning to the area of origin in line with its safeguards. Law Number 18 Year 2017 concerning the Protection of Indonesian Migrant Workers in consideration of letter (d) confirms "that the state must guarantee and protect the rights of its citizens who work both at home and abroad based on the principle of equality, democracy, social justice, gender equality and justice, anti-discrimination, and anti-trafficking in persons", and letter (f) which stipulates that "in the context of services for placement of Indonesian migrant workers abroad it must be carried out in an integrated manner between central and regional government agencies and community participation in a legal system to protect Indonesian workers placed abroad".

The Regional Government provides one-stop integrated services and facilitates the departure and return of Indonesian Migrant Workers. Indonesian migrant workers departing must have competence or expertise. Likewise, for Indonesian Migrant Workers after work, the Regional Government in collaboration with the Central Government provides entrepreneurial training to Indonesian Migrant Workers and their families. In order to provide easy, inexpensive, fast, and safe placement and protection services, one-stop integrated services perform services in accordance with Law Number 25 of 2009 concerning Public Services and Government Regulation Number 96 Year 2OL2 concerning Implementation of Law Number 25 Year 2009 concerning Public Services. One-stop integrated services provide services in the management of document requirements and administration for the placement and protection of Indonesian Migrant Workers and / or Indonesian Migrant Workers and together with the Central Government to recruit and prepare services for administrative requirements. Job training is carried out by government or private employment training institutions that are accredited to prospective Indonesian Migrant Workers. This law emphasizes and gives a greater role to the government and reduces the role of the private sector in the placement and protection of Indonesian migrant workers. ${ }^{1}$

Law No. 18 Year 2017 also provides protection guarantees Social for Indonesian Migrant Workers, which have been carried out by insurance companies that are members of the insurance consortium with the protection program, covering pre-placement, placement and post-placement protection. The protection role is currently transferred and implemented by the Social Security Organizing Agency (BPJS) in accordance with Law Number 40 of 2004 concerning the National Social Security System and Law Number 24 Year 2011 concerning the Social Security Organizing Body. For certain risks not covered by the Social Security program, BPJS can work with institutions government or private. Provisions governing placement and protection. Indonesian Overseas Workers in Law Number 39 of 2004 concerning the Placement and Protection of Indonesian Migrant Workers Abroad has not fulfilled the needs of Indonesian Migrant Workers' Protection. Law Number 39 of 2004 concerning the Placement and Protection of Indonesian Migrant Workers Abroad has not regulated the division of duties and authority between the Central Government, Regional Governments, and the private sector proportionally. Based on these considerations, there needs to be a fundamental change to Law No. 39 Year 2002 concerning the Placement and Protection of Indonesian Migrant Workers Abroad, namely the establishment of a new Law which focuses on the regulation of the Protection of Indonesian Migrant Workers. In this Law, the role of protecting Indonesian Migrant Workers is handed over to both central and government area, starting from before work, during work, and after work. The private sector was only given the role of the organizer of the placement of Indonesian Migrant Workers. ${ }^{2}$

The ASEAN Community has come into force on 31 December 2015 with three pillars i.e. ASEAN Economic Community, ASEAN Political and Security Community and ASEAN Socio-Cultural Community. Indonesian migrant workers (IMW) have tremendous potential to develop. Statistics of the National Agency for the Placement and Protection of Indonesian Workers (BNP2TKI) shows the placement of IMW in 2011 with

\footnotetext{
${ }^{1}$ General Explanation of the Law Number 18 Year 2017 concerning the Protection of Indonesian Migrant Workers
}

${ }^{2}$ General Explanation of the Law Number 18 Year 2017 concerning the Protection of Indonesian Migrant Workers 
586.802 people, 494.609 people (2012), 512.168 persons (2013), 429.872 people (2014) and 275.736 people in 2015. Statistics shows a significant number of migrant workers abroad. Interesting facts of Indonesia's migration for works in Southeast Asia, Malaysia became the country with the largest number of placements. Followed by Singapore, Brunei Darussalam and Thailand. These four ASEAN member countries are located among 25 countries placement of IMW from the distribution of 170 countries. Convergence theory became the theoretical framework used in this study. The method used is literature study to trace the sources of information relevant to this study. This study concludes that IMW has the opportunity to access employment which has been agreed upon by ASEAN member countries through Mutual Recognition Agreements (MRA), however the profession agreed by MRAs still needs support for its development from the Indonesian government in order to be optimally utilized. While the challenge faced is the profile of IMW is still dominated by informal workers, so it takes the Indonesian government efforts to increase interest as a formal workforce. ${ }^{1}$

Law Number 18 Year 2017 is directed to the right position according to their expertise, skills, talents, interests and abilities by paying attention to dignity, human rights, legal protection, equal employment opportunities and availability of labor by prioritizing national interests.

The equitable study and protection of Indonesian labor migrants abroad in 2007 identified that in the placement of migrant workers abroad there were problems that disadvantaged Indonesian migrant workers and the state, limitations and deviations in implementation could be found in planning, implementation and weak supervision. In terms of planning and operations there are weaknesses in managing information on job vacancies abroad and how prospective TKIs are prepared. The utilization of foreign employment opportunities is still in the informal sector (use of services not incorporated). Even if the placement in the formal sector continues to increase, but in terms of the quality of TKI, it is limited to filling in positions that only require basic skills such as those placed in Malaysia. The Malaysian immigration office recorded foreign workers from 22 countries totaling 1,914,053, more than three-fifths $(61.46 \%)$ coming from Indonesia. Those who worked as household managers in the middle of 2007 numbered approximately 320,000 people, the largest part of this type of work (PLRT/PRT) reached the number of 300,000 female workers from Indonesia. On the basis of the above facts and before being able to shift the share of the labor market to the formal sector with higher quality qualifications for Indonesian migrant workers, there is no other choice, the government is required to continue to improve the guidance and protection system for Indonesian workers employed abroad. For the purpose of optimal service, the guidance and protection system start from the stage of preparing Indonesian Migrant Workers (CTKI), when migrant workers abroad until full placement. Political will for that is clear with the existence of rules in Law Number 18 Year 2017 concerning the need for implementing regulations, including: the need for Government Regulations on Provisions for granting protection during the placement of migrant workers abroad, the need for Government Regulations concerning Termination and prohibition of placement of TKI, and the need for Government Regulations regarding the TKI training and protection program.

All the implementing regulations are urgent and need to be consistent in their implementation, given the problem of migrant workers who have not been resolved from time to time. Laila Najib, et.al., ${ }^{2}$ stated that the potential occurrence of violations affecting TKI was thought to originate from the preparation period in the country, in the form of lack of correct information and weak supervision and the low quality of prospective migrant workers. The situation is used by individual placement officers (PL) to recruit prospective migrant workers. Factors in the absence of employment in the village and the existence of success stories of former migrant workers are driving job seekers and housewives to become migrant workers. Deviations occur in the form of original but false information about the identity of migrant workers such as age, marital status, family permission, address and education completed. As a result, it makes it difficult for TKI and TKI service providers inside and outside the country, as well as families if later problems arise.

In connection with the above issue, the Director of Protection of Indonesian Citizens and Indonesian Legal Entities of the Indonesian Ministry of Foreign Affairs stated that the success of the placement and protection of Indonesian migrant workers abroad is highly related and influenced by several factors:

1. Upstream factors, namely how to prepare TKI/TKW to carry out their work, amid intense competition in the international labor market;

\footnotetext{
${ }^{1}$ Achmad Zulfikar, Peluang dan Tantangan Pekerja Migran Indonesia dalam Masyarakat Ekonomi ASEAN, The paper was presented at the 2016 National Convention on the Association of International Relations in 2016 at Hasanuddin University, Makassar, Indonesia on 23-24 November 2016, p.1

${ }^{2}$ Laila Najib, et.al., 2002
} 
2. There is a "missing link" from the placement system, namely (i) opening the TKI market abroad and preparing prospective workers who are needed. (ii) Indonesian representatives abroad do not have comprehensive data on "skilled" and "semi-skilled" TKIs.

3. Problems of coordination between agencies, the number of nodes that need to be improved, especially the phase of preparing TKI/TKW.

Law Number 18 Year 2017 concerning the Protection of Indonesian Migrant Workers it is said that "Indonesian Workers are every Indonesian citizen who meets the requirements to work abroad in employment relations for a certain period of time by receiving wages". Employment Relations means the relationship between employers or employers with workers or laborers based on work agreements that have elements of employment, wages and orders.

The working relationship between the use of Indonesian labor and the new employer occurs after the work agreement has been agreed upon and signed by the parties. In other words, every Indonesian workforce who will work abroad must be based on a signed employment agreement before the person is dispatched to work abroad. A work agreement is a written agreement between Indonesian workers and users of work that contains work conditions, rights, and obligations of each party.

Every prospective Indonesian worker who wants to be placed abroad must be given sufficient provisions to work, up to the end of the placement briefing. Debriefing of the End of Placement is an activity of giving or informing prospective Indonesian workers who will go abroad. Prospective Indonesian workers have mental and knowledge readiness to work abroad.

In Article 27 paragraph 2 of the 1945 Constitution, it is said that every citizen of the Republic of Indonesia has the right to obtain decent work and livelihood for humanity. Every Worker has the same rights and opportunities to choose, get, change jobs, and earn a decent income, both domestically and abroad with his skills, skills, talents, interests and abilities. To realize the rights of Indonesian migrant workers, the government is responsible for seeking to expand employment opportunities, both at home and abroad. Furthermore, the government regulates the placement of Domestic Workers (PTKDN) and Placement of Foreign Workers (PTKLN) more flexibly.

The protection of prospective Indonesian Migrant Workers and Indonesian Migrant Workers aims to: ${ }^{1}$

a. guarantee the fulfillment and enforcement of human rights as citizens and Indonesian Migrant Workers; and

b. guaranteeing legal, economic and social protection of workers Indonesian Migrants and their families.

The main points of regulation in this Law include Indonesian Migrant Workers who work for legal entities, Indonesian Migrant Workers who work for Individual Employers, sailors of fishermen and seafarers, rights and obligations of Indonesian Migrant Workers and their families, Workers' Protection efforts Indonesian migrants are well protected in the placement system (before work, during work, and after work), labor attaché, one-stop integrated services, financing systems that are in favor of Indonesian Migrant Workers and Indonesian Migrant Workers, implementation of Indonesian Migrant Workers' Social Security, and protection legal, social and economic. This Law also regulates the duties and authority of the Central Government and Regional Government, as well as the role and function of the Agency as the executor of the Indonesian Migrant Workers Protection policy. In this Law, the National Agency for the Placement and Protection of Indonesian Workers formed under Law No. 39 Year 2004 strengthened its function and role as the executor of protection for Indonesian Migrant Workers. In the implementation of the Indonesian Migrant Workers Protection strict supervision and law enforcement is needed. Supervision includes protection before work, during work, and after work. Law enforcement includes administrative sanctions and criminal sanctions. ${ }^{2}$

The government and the community together seek to expand employment opportunities at home and abroad, including within and outside the employment relationship. Law Number 18 Year 2017 concerning the Protection of Indonesian Migrant Workers states that the placement of migrant workers is a service activity and brings together migrant workers according to their talents and abilities with employers abroad which includes the

\footnotetext{
${ }^{1}$ General Explanation of the Law Number 18 Year 2017 concerning the Protection of Indonesian Migrant Workers
}

${ }^{2}$ General Explanation of the Law Number 18 Year 2017 concerning the Protection of Indonesian Migrant Workers 
entire recruitment process, document management, education and training, shelter, preparation and departure, departure to the destination country and return from the destination country. In other words, the placement of migrant workers includes pre-placement, placement and repatriation of workers to their original place or after placement. All of that needs to be regulated in such a way by the government and monitoring it so as to create a guarantee of better protection for every Indonesian citizen, especially workers abroad. Labor Placement abroad can provide 3 advantages, namely (1) Overcoming some problems in unemployment in the country or the absorption of labor, (2) Can increase the income of the country's foreign exchange, and (3) Increase the welfare or standard of living of Indonesian labor families. On the other hand, in addition to these benefits there is a negative side, namely the risk of the possibility of inhumane treatment of Indonesian workers abroad. For this reason, it is necessary to increase the protection of Indonesian workers abroad.

\section{Conclusion}

Many Indonesians depart in various ways abroad, especially countries bordering land and sea, such as Malaysia. Some of them even become Malaysians. In its development, the trend of overseas migration is increasing. This fact is used by some people to be used as business land. They take care of the departure of people from various regions to work abroad, in a way and their shrewdness is barely managed by the state. The practice lasts a dozen years. Only, in 1969 the Indonesian Ministry of Labor regulated and supervised the placement of Indonesians working abroad, which became popular as the name of Indonesian migrant workers. The rules contained in Government Regulation No.4 of 1970 concerning Inter-Work, the Inter-State Inter-Work Program is permitted (Antar Kerja Antar Negara/AKAN). The placement of migrant workers involves the private sector. In 2003, Indonesia had a new law on employment, namely Law No. 13 Year 2003 concerning Manpower. Regarding the placement and protection of migrant workers, this Law mandates the need for special laws governing this. A year later, Law No. 39 Year 2004 was issued concerning the Placement and Protection of Indonesian Workers.

\section{References}

Abdul Maasba Magassing, et.al., Use of the Memorandum of Understanding Model on Legal Protection of Indonesia Migrant Workers, Journal of Law, Policy and Globalization, Vol. 67, 2017.

Achmad Zulfikar, Peluang dan Tantangan Pekerja Migran Indonesia dalam Masyarakat Ekonomi ASEAN, The paper was presented at the 2016 National Convention on the Association of International Relations in 2016 at Hasanuddin University, Makassar, Indonesia on 23-24 November 2016.

Brenda Yeoh, et.al., 2000, Global Cities, Transnational Flows and Gender Dimensions: The View from Singapore. Departement of Geography, Univ.of Singapore, Royal Dutch Geographical Society KNAG.

Fadjri, et.al., Pelayanan, Penempatan, dan Perlindungan Tenaga Kerja Indonesia, Kasus Pendataan Selapajang, Leuser Cita Pustaka, Jakarta, 2010.

ILO, Perlindungan \& Pencegahan Untuk Pekerja Migran Indonesia, Jakarta, without year.

ILO World of Work Report 2014

Kadarudin, People Smugling Dalam Perspektif Hukum Internasional dan Penegakan Hukumnya di Indonesia, Jurnal Perpustakaan, Informasi dan Komputer "Jupiter" Vol. XII No. 2, 2013, UPT. Perpustakaan Universitas Hasanuddin.

Koesrianti, 2010, Kewajiban Negara Pengirim dan Negara Penerima Atas Perlindungan Pekerja Migran, Jurnal Diplomasi, Vol. 2. No. 1.

Law of the Republic of Indonesia Number 18 Year 2017 concerning the Protection of Indonesian Migrant Workers.

Muhaimin Iskandar, Pisau Bermata Dua: Menuju Cita TKI yang Bermartabat dan Bermanfaat, Jakarta: Kementerian Tenaga Kerja dan Transmigrasi, 2014. 
Nurdin Widodo, Permasalahan Tenaga kerja Indonesia di daerah Asal: Studi Kasus Kabupaten Tulungagung Jawa Timur. Jurnal penelitian dan Pengembangan Kesejahteraan Sosial, Vol. 14, No. 1, 2009.

Peter Mahmud Marzuki, Penelitian Hukum, Jakarta: Kencana, 2011.

Policy Assessment and Development Agency of the Ministry of Foreign Affairs Policy, 2016, Basic Position of Indonesian Foreign Policy, Indonesian Ministry of Foreign Affairs.

R.A.W. Ajeng, Kerjasama BNP2TKI Dengan IOM dalam Menangani Human Trafficking Tenaga Kerja Indonesia Di Malaysia Periode 2011-2015, Journal of International Relations, Vol. 2, No. 1, 2016.

S. Djuni Prihatin, Potret Buram Perlindungan Tenaga Kerja Indonesia, Jurnal Ilmu Sosial dan Ilmu Politik Vol. 10, No. 3, 2007.

VOA Indonesia: Aktivis: Pekerja Migran Indonesia Masih Rentan Terhadap Berbagai Perlakuan Kejam, November 12, 2018 edition, see https:/www.voaindonesia.com/a/aktivis-pekerja-migran-indonesiamasih-rentan-terhadap-berbagai-perlakuan-kejam/4654625.html 